J. Dairy Sci. 95:5831-5844

http://dx.doi.org/10.3168/jds.2011-5042

(C) American Dairy Science Association ${ }^{\circledR}, 2012$.

\title{
Effects of source of trace minerals and plane of nutrition on growth and health of transported neonatal dairy calves ${ }^{1}$
}

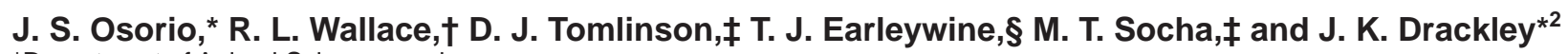 \\ *Department of Animal Sciences and \\ †Department of Veterinary Clinical Medicine, University of Illinois, Urbana 61801 \\ ‡Zinpro Performance Minerals, Eden Prairie, MN 55344 \\ §Land O' Lakes Animal Milk Products Inc., Shoreview, MN 55126
}

\section{ABSTRACT}

The aims of the experiment were to evaluate the effects of source of trace minerals (TM) and plane of nutrition (PN) early in life on growth and health of transported calves. Ninety male Holstein calves $<1 \mathrm{wk}$ old were assigned to treatments in a $2 \times 2$ factorial arrangement of $\mathrm{PN}$ and $\mathrm{TM}$ source in a randomized complete block design. Calves assigned to low PN $(\mathrm{LPN})$ received milk replacer $[22 \%$ crude protein $(\mathrm{CP})$, $20 \%$ fat, $568 \mathrm{~g}$ of powder/d for wk 1 to 4 , and $284 \mathrm{~g}$ of powder/d for wk 5] plus ad libitum access to starter [18\% CP, dry matter (DM) basis, for wk 1 to 12] and a limited amount of hay $(0.5 \mathrm{~kg} / \mathrm{d}$ as fed, for wk 10 to 12); LPN calves were weaned at 6 wk. During wk 13 to 20 , LPN calves were fed $3.2 \mathrm{~kg} / \mathrm{d}$ of grower mix $(16 \%$ CP, DM basis) plus chopped hay for ad libitum intake. Calves assigned to high PN (HPN) received variable amounts of milk replacer $(28 \% \mathrm{CP} ; 20 \%$ fat; and 810 , 1,136 , and $568 \mathrm{~g}$ of powder/d for wk 1, 2 to 6 , and 7, respectively) plus ad libitum access to starter $(22 \% \mathrm{CP}$, DM basis, wk 1 to 12$)$ and limited hay $(0.5 \mathrm{~kg} / \mathrm{d}$ as fed, for wk 10 to 12 ); HPN calves were weaned at wk 7. Calves assigned to HPN were offered grower mix for ad libitum intake plus a limited amount of chopped hay $(0.5 \mathrm{~kg} / \mathrm{d}$, as-fed basis) from wk 13 to 20 . Milk replacers were formulated to contain balanced amounts of either inorganic (I) or organic (O) TM (50, 50, 10, and 100 $\mathrm{mg} / \mathrm{kg}$ of $\mathrm{Zn}, \mathrm{Mn}, \mathrm{Cu}$, and $\mathrm{Fe}$, respectively), whereas respective ITM or OTM starters and growers contained $\mathrm{Zn}, \mathrm{Mn}, \mathrm{Cu}$, and $\mathrm{Co}$ at 70, 55, 12, and $1 \mathrm{mg} / \mathrm{kg}$. The HPN treatments increased final body weight and stature measurements, average daily gain, and gain-to-feed

\footnotetext{
Received October 11, 2011.

Accepted May 24, 2012.

${ }^{1}$ Supported in part by funds from the State of Illinois and US Department of Agriculture-Cooperative State Research, Education, and Extension Service (USDA-CSREES) appropriated to the Illinois Agricultural Experiment Station.

${ }^{2}$ Corresponding author: drackley@illinois.edu
}

ratio through wk 20. Starter intake was lower for calves fed HPN. The OTM increased growth when supplemented to HPN but not when supplemented to LPN. During the liquid-feeding period, fecal scores were more fluid for calves fed HPN but measures of health status did not differ among diets. Results indicated that an enhanced nutritional program during early life allowed calves to have greater overall growth and maintain a normal health status throughout the preweaning period. High PN and OTM were synergistic in increasing early growth of calves.

Key words: trace mineral, calf growth, milk replacer

\section{INTRODUCTION}

Growth and health in newborn dairy calves can be impaired by poor maternal nutrition, difficult calving, colostrum deprivation, and stressors such as transportation; however, these can be mitigated to some extent with quality management and adequate early nutrition. It has been well documented that feeding more milk replacer of higher protein content (so-called accelerated or enhanced nutrition) improves early growth performance (Diaz et al., 2001; Cowles et al., 2006; Hill et al., 2006a). On the other hand, some studies have concluded that enhanced nutrition programs might have a negative effect on health status and, consequently, on overall production cost (Hill et al., 2006a; Quigley et al., 2006), particularly for transported calves with questionable colostrum status.

Optimal early growth performance of dairy calves is the main target of enhanced early nutrition programs; by increasing DMI of milk replacer calves grow faster and more efficiently early in life. This program contrasts with conventional nutrition programs in which limited amounts of milk replacer are fed to encourage early starter consumption and lower daily feed costs. Enhanced early nutrition capitalizes on the fact that growth performance early in life is driven more by increasing protein and lactose intake than by increasing fat intake (Tikofsky et al., 2001; Hill et al., 2008). 
Negative effects on health status such as increased morbidity (primarily scouring) and use of antibiotics have been attributed to enhanced early nutrition programs (Hill et al., 2006a; Quigley et al., 2006). However, scouring is not reflected in simply more fluid feces, which should be accepted as a physiological adjustment to increased energy and solids intake. Consequently, improved health status might be better reflected in less use of antibiotics and electrolytes.

Trace minerals (TM) play critical roles in structural development and function of many cellular systems, one of which is the immune system. It is imperative, therefore, that adequate TM status is established at birth and maintained to ensure that sufficient stores are available for optimal animal performance and for when animals become challenged by disease or stressors. Organic or bioavailable TM have been demonstrated to enhance health status in dairy cattle, especially during times of stress, such as the periparturient period (Ballantine et al., 2002; Nocek et al., 2006; Griffiths et al., 2007; Siciliano-Jones et al., 2008). Transportation is an important stressor that can affect immunological status by increasing hormones such as cortisol and acute-phase proteins that can eventually lead to decreased DMI (Stanger et al., 2005); transportation was the stressor used in this trial. Because of the greater nutrient demands for more rapid growth, biological and economic benefits of organic TM might be more pronounced in enhanced early nutrition programs. Therefore, the objective of this study was to determine the effects of source of TM and plane of nutrition $(\mathbf{P N})$ on growth and health of transported neonatal dairy calves.

\section{MATERIALS AND METHODS}

\section{Experimental Design and Calf Management}

All procedures were conducted under protocols approved by the University of Illinois Institutional Animal Care and Use Committee. Ninety male Holstein calves less than 1 wk old were purchased by a buyer in 3 groups of 30 to 35 calves from farms in southern Wisconsin and transported (ca. $4 \mathrm{~h}$ ) to the Nutrition Field Laboratory site at the University of Illinois (Urbana). Calves were stratified by arrival BW and were assigned to 1 of the 4 experimental treatments $(\mathrm{n}=$ at least 22 per treatment). The experimental design was a randomized block design with a $2 \times 2$ factorial arrangement of treatments. Throughout the experiment, the mean maximum, mean minimum, and mean daily temperatures were $15.3,4.5$, and $9.9^{\circ} \mathrm{C}$, respectively. Maximum and minimum relative humidity was 88.5 and $51.2 \%$, respectively.
Calves remained at the Field Laboratory facility from arrival through wk 12, and then were transported $(<0.5 \mathrm{~h})$ to the University of Illinois Beef Research Unit for housing through wk 35. Calves were housed in individual hutches from arrival through wk 9, and then were grouped by treatment in super-hutches (4 to 7 calves per hutch) through wk 12. Calves were housed in the same groups of 4 to 7 calves by original treatment from wk 13 to 20 , and then were commingled from wk 21 to 35. During the Field Laboratory phase, straw was used as bedding on a sheet of weed barrier cloth over a base of crushed rock; calves were housed on rubber-covered concrete slatted floors in pens at the Beef Research Unit. Hutches were washed and sanitized between groups of calves. All calves were castrated via surgical removal of gonads at 1 wk after arrival.

\section{Dietary Treatments}

The treatments for this study (Tables 1, 2, and 3) were combinations of either low $(\mathbf{L})$ or high $(\mathbf{H})$ PN with either inorganic (I) or organic $(\mathbf{O})$ sources of supplemental TM. Compared with LPN, the HPN treatment consisted of greater amounts and nutrient density of milk replacer and starter, as well as less forage during the growing phase. For the OTM treatment, organic forms of $\mathrm{Zn}, \mathrm{Mn}, \mathrm{Cu}$, and Fe were supplemented in milk replacers (Table 1 ) at 50, 50, 10, and $100 \mathrm{mg} / \mathrm{kg}$, respectively, whereas ITM contained the sulfate forms of these TM at the same concentrations. In starter (Table 2 ) and grower (Table 3) concentrates, organic (OTM) or sulfate (ITM) forms of $\mathrm{Zn}, \mathrm{Mn}, \mathrm{Cu}$, and Co were provided at $70,55,12$, and $1 \mathrm{mg} / \mathrm{kg}$, respectively. The TM sources were incorporated into the appropriate TM premix by the manufacturer before being added into the final diets.

Calves received the LPN plus ITM diet (LI) during the week of arrival (wk 0) as a standardization period, and then were switched to assigned treatments at the beginning of wk 1 . Calves on LPN treatments were kept at the same feeding rate for milk replacer (568 $\mathrm{g} / \mathrm{d})$; in contrast, calves assigned to HPN treatments received $810 \mathrm{~g} / \mathrm{d}$ during wk 1 and 1,136 g of powder/d during wk 2 through 6 . Milk replacers (manufactured by Land O'Lakes Animal Milk Products Inc., Shoreview, MN) contained only milk-derived proteins and were nonmedicated. Milk replacers were reconstituted to $12 \%$ solids for all calves during wk 0 and then 17 and $12 \%$ solids for calves fed $\mathrm{H}$ and $\mathrm{L}$ milk replacers, respectively, until weaning. Starters for HPN and LPN were texturized and differed in contents of CP and ME (Table 2). Fresh starter grain was provided daily and individually by treatment (Table 2) from wk 
Table 1. Chemical composition of milk replacers by treatment

\begin{tabular}{lccccc}
\hline & \multicolumn{7}{c}{ Treatment $^{2}$} \\
\cline { 2 - 5 } Nutrient $^{1}$ & LI & LO & HI & HO & SEM \\
\hline DM (\%) & 93.1 & 93.5 & 94.1 & 94.5 & 0.53 \\
CP (\% of DM) & 23.5 & 23.7 & 28.7 & 29.2 & 0.24 \\
Fat (\% of DM) & 21.6 & 21.4 & 21.3 & 19.7 & 0.64 \\
ME (Mcal/kg) & 3.41 & 3.41 & 3.26 & 3.17 & 0.03 \\
Ca (\% of DM) & 1.09 & 1.08 & 0.79 & 0.80 & 0.01 \\
P (\% of DM) & 0.87 & 0.86 & 0.86 & 0.86 & 0.01 \\
Mg (\% of DM) & 0.15 & 0.15 & 0.14 & 0.14 & 0.002 \\
K (\% of DM) & 2.74 & 2.73 & 2.52 & 2.53 & 0.03 \\
Na (\% of DM) & 1.13 & 1.13 & 1.14 & 1.13 & 0.03 \\
S (\% of DM) & 0.35 & 0.34 & 0.43 & 0.43 & 0.01 \\
Fe (mg/kg of DM) & 126 & 168 & 101 & 126 & 17 \\
Zn (mg/kg of DM) & 50 & 57 & 50 & 59 & 5 \\
Cu (mg/kg of DM) & 13 & 10 & 10 & 11 & 3 \\
Mn (mg/kg of DM) & 52 & 54 & 48 & 52 & 3 \\
Mo (mg/kg of DM) & 1 & 1 & 1 & 1 & 1 \\
\hline
\end{tabular}

${ }^{1}$ Feed samples were taken weekly from wk 1 to 8 and composited in 2 subsamples for each replicate.

${ }^{2} \mathrm{LI}=$ low plane of nutrition $(\mathrm{PN})$, inorganic trace minerals (TM); LO = low PN, organic TM; HI = high PN, inorganic TM; $\mathrm{HO}=$ high $\mathrm{PN}$, organic TM. Inorganic trace minerals ( $\mathrm{Zn}, \mathrm{Mn}, \mathrm{Cu}$, and $\mathrm{Fe}$ ) were provided in sulfate forms. Organic trace minerals ( $\mathrm{Zn}, \mathrm{Mn}, \mathrm{Cu}$, and $\mathrm{Fe}$ ) were supplied by ZINPRO, MANPRO, CuPLEX, and Availa-Fe (Zinpro Performance Minerals, Eden Prairie, MN), respectively.

1 through wk 9 . The starter offered was increased 227 $\mathrm{g} / \mathrm{d}$ when refusal from the previous day was $<136 \mathrm{~g}$. Particle size of the starters was not determined, but no evidence of sorting or settling of fines was noted.
Weaning occurred at the end of wk 6 or 7 for LPN and HPN treatments, respectively. Weaning procedures were according to the standard recommendations of the milk replacer manufacturer and consisted of decreasing

Table 2. Chemical composition of starters by treatment

\begin{tabular}{lrrrrr}
\hline & \multicolumn{4}{c}{ Treatment $^{2}$} \\
\cline { 2 - 4 } Nutrient $^{1}$ & LI & LO & HI & HO & SEM \\
\hline DM (\%) & 87.1 & 87.4 & 87.4 & 87.5 & 0.26 \\
CP (\% of DM) & 22.4 & 21.8 & 25.4 & 26.9 & 1.00 \\
ADF (\% of DM) & 9.9 & 10.1 & 9.2 & 10.4 & 0.66 \\
NDF (\% of DM) & 19.6 & 19.4 & 15.8 & 16.2 & 0.59 \\
Lignin (\% of DM) & 2.5 & 2.7 & 2.5 & 2.4 & 0.28 \\
NFC (\% of DM) & 45.9 & 47.2 & 47 & 44.9 & 1.55 \\
Fat (\% of DM) & 3.6 & 3.4 & 3.2 & 2.8 & 0.15 \\
ME (Mcal/kg) & 3.02 & 3.01 & 3.10 & 3.08 & 0.03 \\
Ca (\% of DM) & 1.34 & 1.32 & 1.27 & 1.35 & 0.08 \\
P (\% of DM) & 0.64 & 0.60 & 0.59 & 0.60 & 0.02 \\
Mg (\% of DM) & 0.24 & 0.23 & 0.22 & 0.23 & 0.01 \\
K (\% of DM) & 1.26 & 1.28 & 1.38 & 1.46 & 0.05 \\
Na (\% of DM) & 1.56 & 1.44 & 1.49 & 1.61 & 0.08 \\
S (\% of DM) & 0.31 & 0.34 & 0.31 & 0.31 & 0.02 \\
Fe (mg/kg of DM) & 277 & 281 & 291 & 293 & 11.2 \\
Zn (mg/kg of DM) & 155 & 148 & 123 & 140 & 1.1 \\
Cu (mg/kg of DM) & 30 & 28 & 28 & 26 & 8.9 \\
Mn (mg/kg of DM) & 110 & 130 & 104 & 101 & 1 \\
Mo (mg/kg of DM) & 1 & 1 & 1 & 1 & 0.3 \\
Co (added mg/kg of DM) & 1 & 1 & 1 & 12 & \\
Cu (added mg/kg of DM) & 12 & 12 & 12 & 55 & \\
Mn (added mg/kg of DM) & 55 & 55 & 55 & 70 & \\
Zn (added mg/kg of DM) & 70 & 70 & 70 & \\
\hline
\end{tabular}

${ }^{1}$ Feed samples were taken weekly from wk 1 to 8 and composited in 2 subsamples for each replicate.

${ }^{2} \mathrm{LI}=$ low plane of nutrition (PN), inorganic trace minerals (TM); LO = low PN, organic TM; HI = high PN, inorganic TM; $\mathrm{HO}=$ high $\mathrm{PN}$, organic TM. Inorganic trace minerals ( $\mathrm{Zn}, \mathrm{Mn}, \mathrm{Cu}$, and $\mathrm{Co}$ ) were provided in sulfate forms. Organic trace minerals ( $\mathrm{Zn}, \mathrm{Mn}, \mathrm{Cu}$, and $\mathrm{Co}$ ) were supplied by ZINPRO, MANPRO, CuPLEX, and COPRO (Zinpro Performance Minerals, Eden Prairie, MN), respectively. 
Table 3. Chemical composition of grower grain mix and chopped hay fed from wk 13 to 20

\begin{tabular}{|c|c|c|c|c|c|}
\hline \multirow[b]{2}{*}{ Nutrient $^{1}$} & \multicolumn{2}{|c|}{ Grain $\operatorname{mix}^{2}$} & \multirow[b]{2}{*}{ SEM } & \multirow{2}{*}{$\begin{array}{c}\text { Chopped } \\
\text { hay }\end{array}$} & \multirow[b]{2}{*}{ SEM } \\
\hline & Inorganic & Organic & & & \\
\hline $\mathrm{DM}(\%)$ & 88.3 & 88.0 & 0.33 & 90.9 & 0.35 \\
\hline $\mathrm{CP}(\%$ of DM $)$ & 24.5 & 22.6 & 1.07 & 12.6 & 0.37 \\
\hline $\mathrm{ADF}(\%$ of DM) & 12.1 & 11.5 & 0.63 & 45.0 & 0.80 \\
\hline NDF ( $\%$ of DM) & 21.4 & 19.6 & 0.50 & 59.8 & 0.90 \\
\hline TDN (\% of DM) & 79.0 & 79.0 & 0.89 & 57.0 & 0.93 \\
\hline $\mathrm{NE}_{\mathrm{M}}(\mathrm{Mcal} / \mathrm{kg})$ & 0.88 & 0.89 & 0.01 & 0.50 & 0.01 \\
\hline $\mathrm{NE}_{\mathrm{G}}(\mathrm{Mcal} / \mathrm{kg})$ & 0.59 & 0.60 & 0.01 & 0.20 & 0.01 \\
\hline $\mathrm{Ca}(\%$ of $\mathrm{DM})$ & 1.76 & 1.51 & 0.14 & 0.82 & 0.06 \\
\hline $\mathrm{P}(\%$ of $\mathrm{DM})$ & 0.92 & 0.81 & 0.05 & 0.23 & 0.01 \\
\hline $\mathrm{Mg}(\%$ of DM $)$ & 0.30 & 0.27 & 0.01 & 0.21 & 0.01 \\
\hline $\mathrm{K}(\%$ of $\mathrm{DM})$ & 1.54 & 1.40 & 0.11 & 2.27 & 0.12 \\
\hline $\mathrm{Na}(\%$ of $\mathrm{DM})$ & 0.45 & 0.39 & 0.03 & 0.03 & 0.00 \\
\hline $\mathrm{S}(\%$ of $\mathrm{DM})$ & 0.32 & 0.29 & 0.02 & 0.14 & 0.01 \\
\hline $\mathrm{Fe}(\mathrm{mg} / \mathrm{kg}$ of $\mathrm{DM})$ & 421 & 381 & 40.7 & 148 & 20.3 \\
\hline $\mathrm{Zn}(\mathrm{mg} / \mathrm{kg}$ of DM) & 179 & 173 & 14.0 & 21 & 0.8 \\
\hline $\mathrm{Cu}(\mathrm{mg} / \mathrm{kg}$ of $\mathrm{DM})$ & 34 & 29 & 2.5 & 8 & 0.7 \\
\hline $\mathrm{Mn}(\mathrm{mg} / \mathrm{kg}$ of $\mathrm{DM})$ & 144 & 140 & 6.8 & 28 & 1.1 \\
\hline Mo (mg/kg of DM) & 1 & 1 & 0.2 & 0.3 & 0.1 \\
\hline Relative feed value & & & & 84 & 1.8 \\
\hline Co (added $\mathrm{mg} / \mathrm{kg}$ of $\mathrm{DM})$ & 1 & 1 & & & \\
\hline $\mathrm{Cu}$ (added mg/kg of DM) & 12 & 12 & & & \\
\hline Mn (added mg/kg of DM) & 55 & 55 & & & \\
\hline $\mathrm{Zn}($ added $\mathrm{mg} / \mathrm{kg}$ of $\mathrm{DM})$ & 70 & 70 & & & \\
\hline
\end{tabular}

milk replacer to 1 feeding daily (284 and $568 \mathrm{~g} / \mathrm{d}$ for LPN and HPN, respectively) during the week preceding weaning. Calves remained in their individual hutches after weaning through wk 9 .

After wk 9, calves were grouped by treatment and fed starter grain for ad libitum intake plus a small amount of chopped hay $(227 \mathrm{~g} / \mathrm{d}$ per calf). The small amount of hay was considered adequate to prevent bloating of calves but did not contribute appreciably to nutrient supply. From wk 13 on, the same general scheme was maintained for groups housed at the Beef Research Unit except that only 1 grower grain mixture was fed to both LPN and HPN, with either I or O supplemental sources of TM for the respective ITM and OTM groups (Table $3)$. For calves on LPN, the amount of grower grain mix containing either ITM or OTM was limited to 3.2 $\mathrm{kg} / \mathrm{d}$, with chopped hay provided for ad libitum intake, whereas calves on HPN were provided grower grain for ad libitum intake but with chopped hay limited to 0.45 $\mathrm{kg} / \mathrm{d}$ per calf. Nutritional treatments were ended after wk 20, at which time calves from all treatments were changed to a common beef cattle growing diet.

\section{Data Collection}

Body conformation measurements including BW, heart girth, body length, withers height, hip height, and hip width were obtained after arrival, weekly until wk 10, and then at wk 12, 15, 20, and 35. All measurements were performed by the same person throughout the experiment to eliminate variation among observers and were taken at 4 to $5 \mathrm{~h}$ after the morning feeding. A blood sample was obtained by jugular venipuncture on d 1 to determine plasma protein concentration immediately by refractometry and $\operatorname{IgG}$ concentration by radial immunodiffusion at a later date (Chigerwe et al., 2008). Health status (fecal scores and respiratory scores) was recorded daily from wk 0 to 9 . For fecal scores, a classification scale from $1=$ firm to $4=$ liquid was used, and for respiratory scores, a scale of $1=$ normal to $5=$ dry cough was used (Table 4). Individual intakes of milk replacer, starter, and water were measured and recorded daily through wk 7, 9, and 7 respectively (Figures 1 and 2 ). Then, daily group intakes of starter mix or grower mix and hay were recorded during the super-hutch and Beef Research Unit stages through wk 20. Milk replacer and starter mix were sampled weekly from wk 1 to 7 and wk 1 through 12, respectively. Samples were composited into 2 and 3 subsamples per replicate for milk replacer and starter mix, respectively. In the same fashion, weekly samples of grain mix and chopped hay were obtained from wk 13 to 20 during the Beef Research Unit phase and composited in 2 subsamples (Table 3). All subsamples were sent to a commercial 


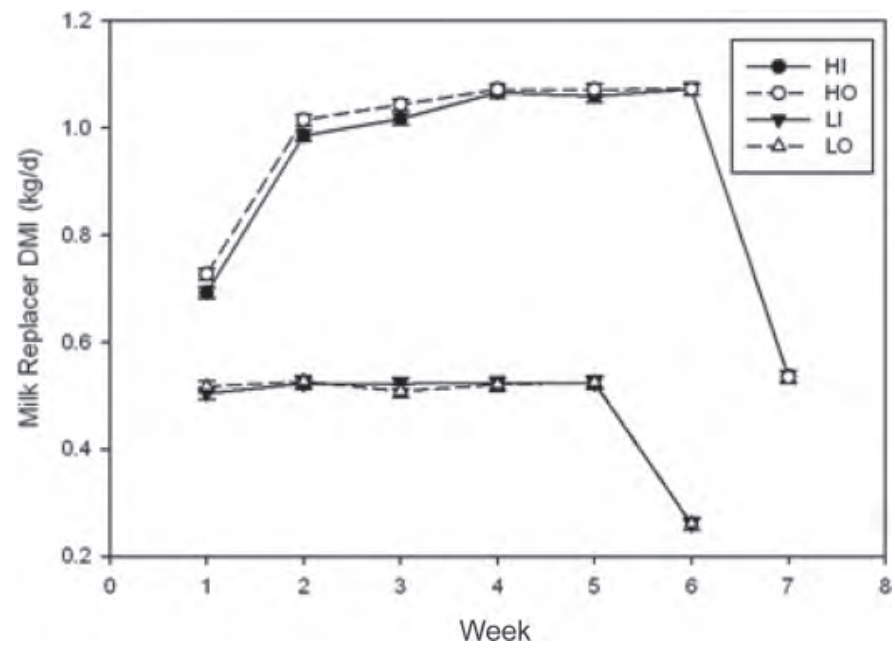

Figure 1. Mean daily intakes (with pooled standard error bars) of milk replacer from wk 1 to 7 for calves fed low (L) planes of nutrition $(\mathrm{PN})$ and inorganic (I) trace minerals (TM) (LI; - $\mathbf{\nabla}-)$, LPN and organic $(\mathrm{O}) \mathrm{TM}\left(\mathrm{LO} ;-\Delta_{-}\right)$, high $(\mathrm{H}) \mathrm{PN}$ and ITM (HI; --), and HPN and OTM (HO; - O-).

laboratory (Dairy One Cooperative Inc., Ithaca, NY), where contents of CP (Leco method; AOAC, 1990), fat (by ether extraction; AOAC International, 2003), and minerals were determined. Minerals were determined using a Thermo Jarrell Ash IRIS Advantage HX Inductively Coupled Plasma Radial Spectrometer (Thermo Instrument Systems Inc., Waltham, MA) and methods as described by Dairy One (2007). Calf BW and stature measurements also were made at wk 35 to determine any residual effects of early nutrition after receiving the same diet from wk 21 through 35 .

\section{Statistical Analyses}

Daily and weekly data were analyzed using the PROC MIXED procedure of SAS 9.1.3 (SAS Institute Inc., Cary, NC). The model contained the fixed effects of replicate (i.e., group of calves), PN, TM source, the interaction of PN and TM source, time (day or week), and interactions of time with PN and TM source. Calf was considered a random effect and nested within PN and TM source. The covariance structures considered for repeated measures analysis were autoregressive 1, compound symmetric, and unstructured; the covariance structure that yielded the lowest Akaike's information criterion was used (Littell et al., 1998). Data from calves that did not complete the experiment were used in the repeated measures analyses, but where data were segmented into periods (e.g., preweaning and postweaning) calves that did not have data for that period were excluded from the analysis. Serum IgG concentration at d 1, BW, body length, heart girth, withers height, hip height, and hip width upon arrival were used as covariates when analyzing the respective measurements. Differences in mortality were compared by use of PROC GENMOD (SAS Institute Inc.). Least squares means were calculated and are presented with standard errors of means. Significance was declared at $P<0.05$ and trends at $P<0.10$.

\section{RESULTS}

\section{Nutrient Composition of Diets}

Nutrient composition of milk replacers and starters is listed by treatment in Tables 1 and 2, respectively. Measured chemical composition of grower grain mixes and chopped alfalfa hay used at the Beef Unit facility can be found in Table 3. Milk replacers for LPN and HPN were formulated to contain 22 and $28 \% \mathrm{CP}$, respectively, on an as-fed basis and actual analyzed $\mathrm{CP}$ on a DM basis was 23.5 and $28.9 \%$, respectively. The starters were prepared to contain 18 and $22 \% \mathrm{CP}$ (asfed basis) for LPN and HPN, respectively. Measured CP contents were 22.1 and $26.1 \%$ on a DM basis, respectively.

Formulation of milk replacers containing OTM aimed to provide 50, 50, 10, and $100 \mathrm{mg} / \mathrm{kg}$ of $\mathrm{Zn}, \mathrm{Mn}, \mathrm{Cu}$, and Fe, respectively; actual chemical analysis indicated that $\mathrm{Zn}, \mathrm{Mn}, \mathrm{Cu}$, and $\mathrm{Fe}$ were 58, 53, 11, and $147 \mathrm{mg} /$ $\mathrm{kg}$, respectively. Similarly, ITM milk replacers contained $50,50,11.5,113.5 \mathrm{mg} / \mathrm{kg}$ of $\mathrm{Zn}, \mathrm{Mn}, \mathrm{Cu}$, and $\mathrm{Fe}$, respectively. Starters with OTM or ITM contained 144,

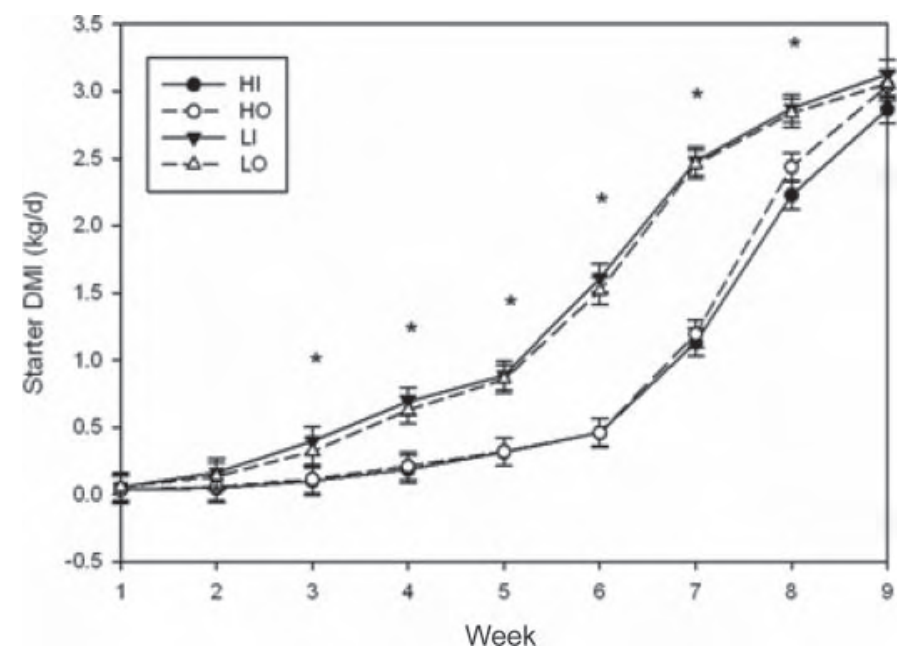

Figure 2. Mean daily intakes (with pooled standard error bars) of starter from wk 1 to 9 for calves fed low (L) planes of nutrition (PN) and inorganic (I) trace minerals (TM) (LI; - $\mathbf{\nabla}$-), LPN and organic $(\mathrm{O})$ TM (LO; - $\Delta-$ ), high (H) PN and ITM (HI;--), and HPN and OTM (HO; -O- $)$. ${ }^{*}$ Denotes effects of PN treatment $\times$ week interactions $(P<$ $0.05)$ over the first 9 wk of age. 
Table 4. Health scores classification

\begin{tabular}{lllll}
\hline & \multicolumn{1}{c}{ Fecal score } & & Respiratory score \\
\cline { 1 - 1 } Score & Description & & Score & Description \\
\hline 1 & Firm, well formed (not hard) & & & Normal \\
2 & Soft, pudding-like & 2 & Runny nose \\
3 & Runny, pancake batter & 3 & Heavy breathing \\
4 & Liquid, splatters & 4 & & Cough moist \\
& & 5 & Cough dry \\
\hline
\end{tabular}

116, 27, and $286 \mathrm{mg} / \mathrm{kg}$ and 139, 107, 29, and $284 \mathrm{mg} /$ $\mathrm{kg}$ for $\mathrm{Zn}, \mathrm{Mn}, \mathrm{Cu}$, and $\mathrm{Fe}$, respectively. In contrast, OTM and ITM starters were formulated to contain 105, 91, 21, and $307 \mathrm{mg} / \mathrm{kg}$ and 104, 90, 21, and $306 \mathrm{mg} /$ $\mathrm{kg}$, respectively.

\section{Intakes}

Mean intakes of milk replacer DM, CP, and ME were greater $(P<0.001)$ for calves fed HPN, as expected (Table 5). Although TM source did not affect DMI, mean intakes of CP were greater $(P=0.02)$ for calves fed OTM. Calves fed HPN treatments received about twice the DMI of milk replacer compared with calves fed LPN treatments (Figure 1). Intakes of DM, CP, and ME from starter were greater $(P<0.001)$ for LPN treatments. Although calves fed LPN treatments had greater starter DMI due to treatment and weaning effects, HPN and LPN calves tended to have similar starter DMI by wk 9 (Figure 2). Total DMI and total ME intake did not differ significantly among treatments through wk 9 (Table 5). Total CP intake was greater $(P<0.05)$ for calves fed the HPN treatments. A compensatory effect on total DMI was observed from wk 1 to 9 , where LPN calves tended to balance their lower DMI during the first 5 wk with an increased total DMI from wk 5 to 9 , with the reverse effects observed for calves fed HPN diets (Figure 3).

Weekly intakes were evaluated in 3 different periods when calves were housed individually: liquid feeding (wk 0 to 4), weaning (wk 5 to 7 ), and postweaning (wk 8 to 9). During the liquid feeding period total DM, $\mathrm{CP}$, and ME intakes were greater $(P<0.001)$ for HPN treatments. Starter DM and CP accounted for $27 \%$ of total DMI and CP intake for LPN treatments; in contrast, starter DM and CP were $5.5 \%$ of total DMI and $\mathrm{CP}$ intake for HPN treatments. Starter ME differed from the previous pattern, contributing 8.3 and $34.2 \%$ of total ME intake for HPN and LPN, respectively (Figure 4).

Throughout the weaning period, total DMI and ME intake were greater $(P<0.05)$ for LPN treatments. However, CP intake was not significantly different among treatments. Amounts of total DMI and CP intake provided by the starter were increased in both HPN and LPN treatments to 59 and $91 \%$ of the total, respectively. Starter ME intake during the same period contributed 40 and $85 \%$ of total ME intake for HPN

Table 5. Mean intakes of DM, CP, and ME from milk replacer and starter, and mean free water intake from wk 1 to 9

\begin{tabular}{|c|c|c|c|c|c|c|c|c|}
\hline \multirow[b]{2}{*}{ Item } & \multicolumn{4}{|c|}{ Treatment $^{1}$} & \multirow[b]{2}{*}{$\mathrm{SEM}^{2}$} & \multicolumn{2}{|c|}{ Contrast $^{3}$} & \multirow[b]{2}{*}{$\mathrm{PN} \times \mathrm{TM}^{4}$} \\
\hline & LI & $\mathrm{LO}$ & $\mathrm{HI}$ & $\mathrm{HO}$ & & I vs. O & $\mathrm{H}$ vs. $\mathrm{L}$ & \\
\hline Milk replacer DM (g/d) & 516 & 514 & 947 & 990 & 18 & 0.60 & $<0.001$ & 0.22 \\
\hline Starter DM $(\mathrm{g} / \mathrm{d})$ & 1,365 & 1,318 & 819 & 873 & 91 & 0.97 & $<0.001$ & 0.58 \\
\hline Total DM $(\mathrm{g} / \mathrm{d})$ & 1,683 & 1,634 & 1,535 & 1,593 & 92 & 0.96 & 0.30 & 0.55 \\
\hline Milk replacer CP (g/d) & $113^{\mathrm{c}}$ & $114^{\mathrm{c}}$ & $264^{\mathrm{b}}$ & $273^{\mathrm{a}}$ & 61 & 0.02 & $<0.001$ & 0.02 \\
\hline Starter CP $(\mathrm{g} / \mathrm{d})$ & 315 & 293 & 211 & 228 & 23 & 0.92 & $<0.001$ & 0.37 \\
\hline Total CP (g/d) & 390 & 368 & 416 & 439 & 23 & 0.99 & 0.03 & 0.32 \\
\hline Milk replacer ME (Mcal/d) & 1.76 & 1.75 & 3.19 & 3.14 & 0.74 & 0.13 & $<0.001$ & 0.28 \\
\hline Starter ME (Mcal/d) & 4.09 & 3.97 & 2.56 & 2.72 & 0.28 & 0.92 & $<0.001$ & 0.60 \\
\hline Total ME (Mcal/d) & 5.18 & 5.04 & 4.91 & 5.0 & 0.28 & 0.93 & 0.57 & 0.67 \\
\hline Free water intake $(\mathrm{kg} / \mathrm{d})$ & 2.24 & 2.23 & 2.70 & 2.88 & 0.65 & 0.72 & 0.02 & 0.69 \\
\hline
\end{tabular}

${ }^{\mathrm{a}-\mathrm{c}}$ Within a row, means without a common superscript are different $(P<0.05)$.

${ }^{1} \mathrm{LI}=$ low $(\mathrm{L})$ plane of nutrition $(\mathrm{PN})$, inorganic $(\mathrm{I})$ trace minerals $(\mathrm{TM}) ; \mathrm{LO}=$ low PN $(\mathrm{LPN})$, organic $(\mathrm{O}) \mathrm{TM}(\mathrm{OTM}) ; \mathrm{HI}=\mathrm{high}(\mathrm{H}) \mathrm{PN}$, inorganic TM (ITM); HO = high PN (HPN), organic TM.

${ }^{2}$ Largest SEM of all treatments.

${ }^{3}$ Contrast statements between ITM and OTM, and between HPN and LPN.

${ }^{4}$ Interaction between PN and TM treatment effects. 


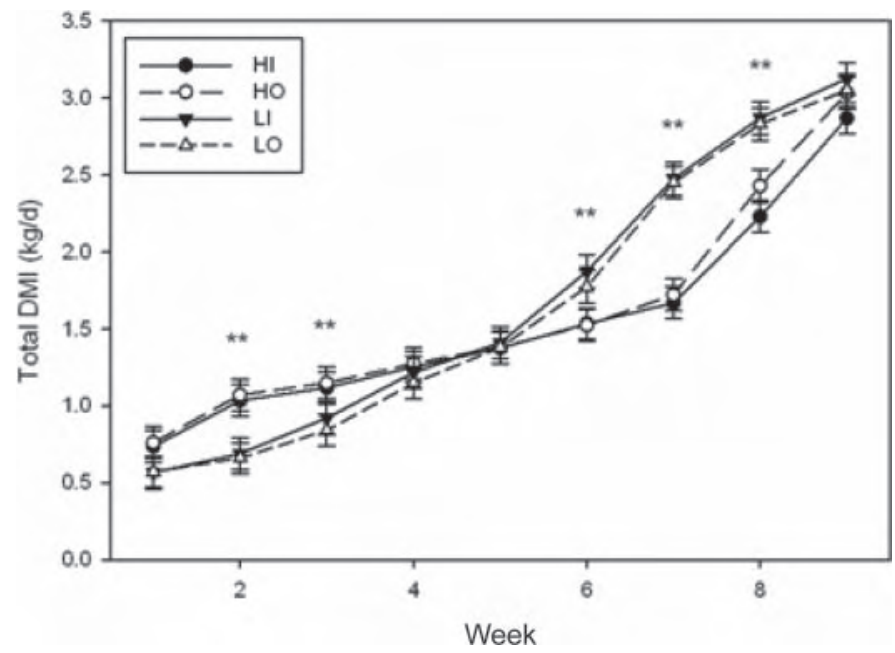

Figure 3. Mean total DMI (with pooled standard error bars) from wk 1 to 9 for calves fed low (L) planes of nutrition (PN) and inorganic (I) trace minerals (TM) (LI; - $\mathbf{-}-)$, LPN and organic (O) TM (LO; $-\Delta$-), high (H) PN and ITM (HI; - - $)$, and HPN and OTM (HO; - O-). ${ }^{* *} P<0.01$ denotes effects of PN treatment $\times$ week interactions over the first 9 wk of age.

and LPN treatments, respectively. Finally, total DMI in the postweaning period was greater for LPN treatments. In contrast, total $\mathrm{CP}$ and ME intakes remained similar for all treatments; the slightly larger ME intake for the LPN treatments (Figure 4) did not achieve statistical significance $(P=0.12)$.

Total water intake, representing free water intake plus water consumed in milk replacer, was greater $(P$ $<0.001$ ) for HPN treatments in comparison with LPN treatments during the first 6 wk (Figure 5). Free water intake was greater $(P=0.02)$ for HPN treatments during the first $5 \mathrm{wk}$ (Table 5). The interaction of PN and week $(P<0.001)$ was explained by quartic and cubic functions for HPN and LPN treatments, respectively, indicating that $\mathrm{PN}$ produced different increments across the weeks of study. As expected, water intake consumed in milk replacer was greater $(P<0.001)$ for calves on HPN treatments as a result of the greater amount of milk replacer fed.

\section{Growth}

Calf BW (Table 6) and body conformation measurements (data not shown) did not differ among treatment groups upon arrival. Final BW and body conformation measurements at wk 20, except for hip width, were greater $(P<0.05)$ for HPN treatments (Table 6). Hip width tended $(P=0.07)$ to be greater for HPN than for LPN. The treatment combination HPN plus OTM (HO) was numerically greater for all traits and was significantly greater $(P=0.05)$ than other treatment combinations in final withers height and hip height (Table 6). Residual treatment effects at wk 35 were not significant for all traits, but heart girth $(P=0.07)$ and hip width $(P=0.09)$ tended to be greater in calves previously fed HPN treatments. The OTM treatments tended $(P=0.10)$ to increase heart girth (Table 7$)$. Mean ADG and gain-to-feed ratio $(\mathbf{G : F})$ were greater $(P<0.04)$ for calves fed HPN treatments than for those fed LPN (Table 6).

Repeated measures analysis over the entire study (Figure 6) showed that the interaction of PN and TM was significant $(P<0.05)$ for withers height and hip height. The same trends for interaction of PN and TM were observed for BW $(P=0.16)$, heart girth $(P=$ $0.11)$, and body length $(P=0.07)$ but differences were not statistically significant. The treatment combination $\mathrm{HO}$ was greater than other treatment combinations for body length $(P=0.02)$, withers height $(P=0.003)$, and hip height $(P=0.003)$. Also, withers height and hip height were greater $(P<0.05)$ for OTM. The interaction of $\mathrm{PN}$ and week was significant $(P<0.05)$ for all body conformation characteristics, meaning that HPN and LPN treatments affected growth at different rates over time.

Growth data were then analyzed in 5 different periods: liquid feeding (wk 0 to 4), weaning (wk 5 to 7 ), postweaning (wk 8 to 12), growing (wk 15 to 20), and residual (at wk 35). Throughout the liquid feeding period, calves fed HPN were larger than those fed LPN for BW, heart girth, body length, and hip width (Table 7). Also, the same trend was observed for withers height but differences between HPN and LPN treatments did not reach statistical significance $(P=0.17)$. Organic TM resulted in greater withers height and hip height than ITM $(P=0.05)$. The interaction of PN and TM was significant $(P<0.05)$ for all traits except body length and hip width; the treatment combination $\mathrm{HO}$ resulted in greater $(P<0.05)$ growth.

During the weaning period, the HPN treatments were superior $(P<0.05)$ to LPN for all growth traits measured (Table 7). Organic TM tended to have a larger effect than ITM on withers height $(P=0.08)$ and hip height $(P=0.08)$. Interactions of $\mathrm{PN}$ and TM $(P<$ $0.05)$ were observed for withers height and hip height, with a tendency for interaction in body length $(P=$ 0.07). Organic TM had a greater effect than ITM when applied in combination with HPN for body length, withers height, and hip height; clear tendencies for the same effects were noted for BW and hip width $(P=$ 0.06 and $P=0.07$, respectively).

During the postweaning period, HPN resulted in a greater response for all traits except withers height and 

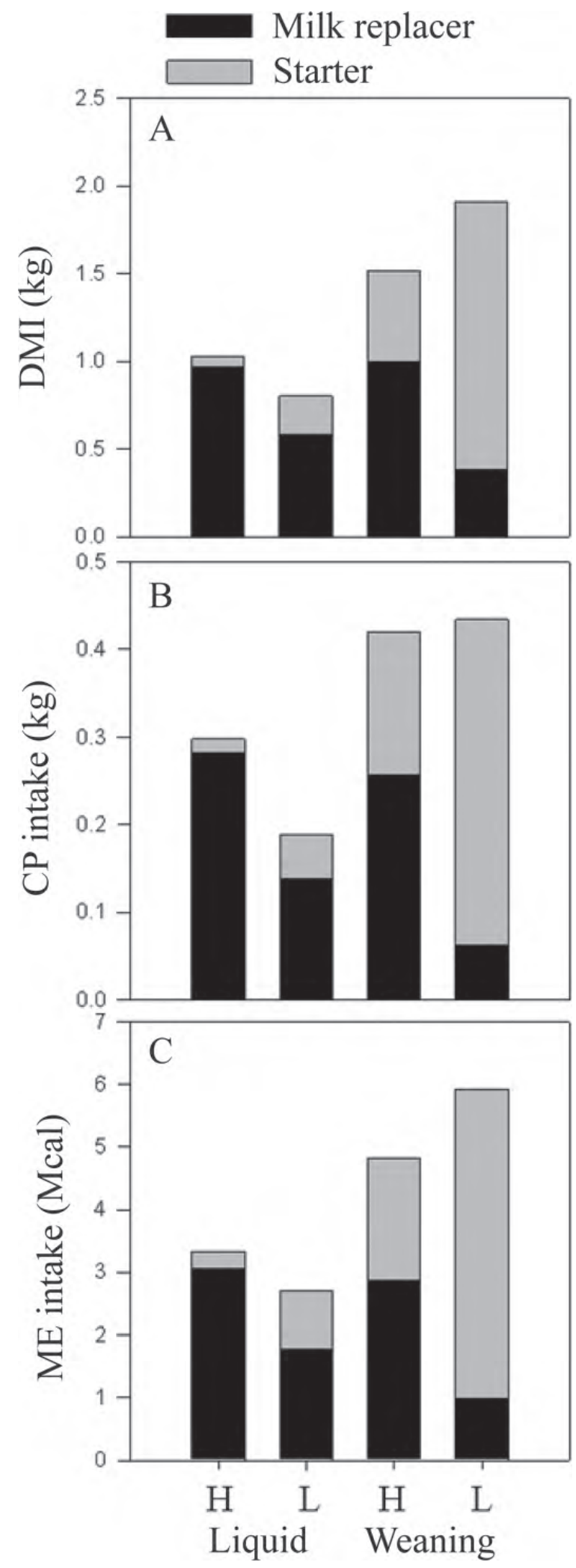

Figure 4. Mean contribution of milk replacer or starter by plane of nutrition (PN) to total DM (panel A), total CP (panel B), and total $\mathrm{ME}$ (panel $\mathrm{C}$ ) intakes during the liquid and weaning periods from wk 0 to 4 and wk 5 to 7 , respectively. $\mathrm{H}=$ high $\mathrm{PN}$ and $\mathrm{L}=$ low $\mathrm{PN}$. hip width (Table 7). Organic TM tended to result in greater withers height $(P=0.07)$ and hip height $(P=$ 0.08). The interaction of PN and TM tended to affect withers height, hip height, and body length $(P=0.10$, $P=0.08$, and $P=0.09$ respectively). In the case of $\mathrm{BW}$, the interaction effects did not reach statistical relevance $(P=0.16)$. The treatment combination $\mathrm{HO}$ was significantly greater $(P<0.05)$ for withers height and hip height and numerically larger for the other traits.

During the growing period, calves fed HPN were greater $(P<0.05)$ than those fed LPN for all traits analyzed, with the exception of hip width (Table 7 ). Comparisons between OTM and ITM did not reach statistical significance for withers height and hip height ( $P=0.14$ and $P=0.17$, respectively). The treatment combination $\mathrm{HO}$ was significantly greater than other treatments for hip height and numerically superior for the rest of the traits analyzed.

Throughout the liquid feeding period ADG was greater $(P<0.001)$ for HPN and the interaction of PN and TM was significant $(P<0.05)$, with treatment HO greater than other treatments (Figure 7). The same pattern was observed for G:F, with the exception that the improved efficiency for HO only tended to be greater $(P=0.06)$ than other treatments (Figure 8$)$. Treatments did not affect ADG during the weaning and postweaning periods. A trend $(P=0.07)$ for greater ADG for HPN was observed during the growing period, whereas LPN treatments actually decreased ADG. High PN had greater $(P<0.001)$ G:F during the weaning period; however, treatment effects were not significant postweaning. Analysis of residual treatment effects at wk 35 showed a tendency for greater $(P=0.08)$ ADG from wk 21 to 35 for calves previously fed OTM. The interaction of PN and TM was significant $(P<0.05)$, with treatment LO greater than other treatments.

\section{Health}

Calves fed HPN treatments presented more $(P<$ 0.001) fluid feces than those fed LPN (Table 8). Also, the interaction of PN and TM indicated that the HI treatment had a greater fecal score than other treatments. The same pattern was observed with days scoured where HPN treatments had, on average, 3 more $(P<0.05)$ days with fluid feces than did calves on LPN treatments. In addition, the HI treatment had $\geq 1.6$ more days with high fecal scores than other treatments. As a consequence, use of electrolytes to maintain fluid balance was greater $(P=0.05)$ for $\mathrm{HI}$ than the other 3 treatments. Mean respiratory score was not different $(P$ $>0.50$ ) among treatments.

Analyzed IgG concentrations did not differ significantly among treatments at the beginning of the exper- 
Table 6. Initial and final BW, final body conformation measurements at wk 20, ADG, and feed efficiency (gain-to-feed ratio, G:F) for calves fed treatments varying in plane of nutrition (PN) and trace minerals (TM) source

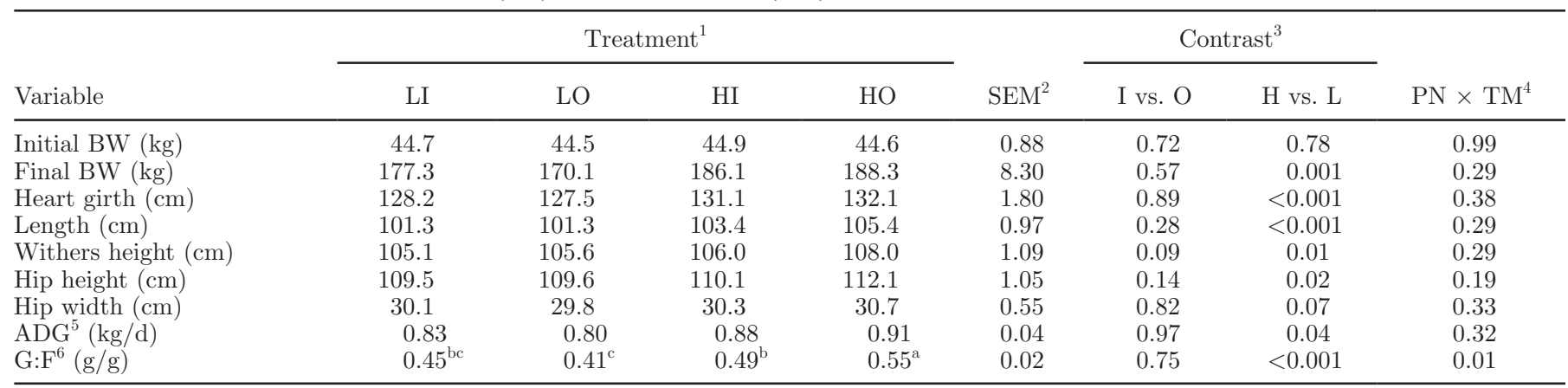

${ }^{\mathrm{a}-\mathrm{C}}$ Within a row, means without a common superscript are different $(P<0.05)$.

${ }^{1} \mathrm{LI}=$ low $(\mathrm{L}) \mathrm{PN}$, inorganic (I) TM; LO = low PN (LPN), organic (O) TM; HI = high (H) PN, inorganic TM (ITM); HO = high PN $(\mathrm{HPN})$, organic TM (OTM).

${ }^{2}$ Largest SEM of all treatments.

${ }^{3}$ Contrast statements between ITM and OTM, and between HPN and LPN.

${ }^{4}$ Interaction between PN and TM treatment effects.

${ }^{5}$ Average daily gain was calculated from wk 1 to 20 .

${ }^{6}$ Gain-to-feed ratio was calculated from wk 1 to 9 .

iment. However, calves assigned to HPN diets tended $(P=0.12)$ to have a higher IgG upon arrival; therefore, as described, the initial IgG was used as a covariate in statistical analyses. During the study, mortality did not differ significantly $(P=0.67)$ despite the range between HPN and LPN. In addition, the survival curve (Figure 9) illustrates the apparently greater effect of stressors early in life between wk 1 and 2, where all treatments experienced a decrease in the percentage survival.

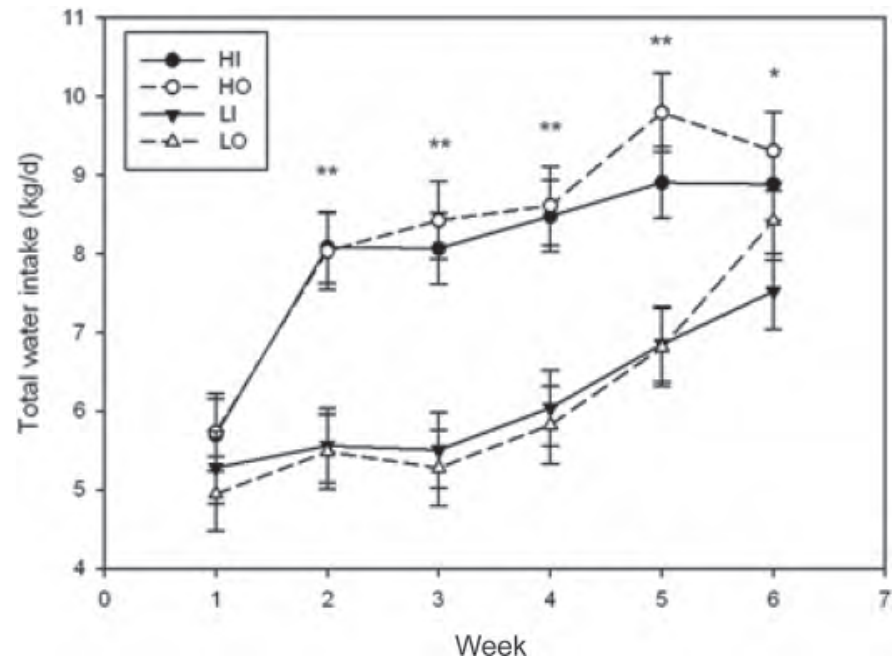

Figure 5. Mean daily intakes (with pooled standard error bars) of total water from wk 1 to 9 for calves fed low (L) planes of nutrition (PN) and inorganic (I) trace minerals (TM) (LI; - $\mathbf{\nabla}-)$, LPN and organic (O) TM (LO; - $\Delta$-), high (H) PN and ITM (HI; - - ), and HPN and OTM $(\mathrm{HO} ;-\mathrm{O}-)$. ${ }^{*} P<0.05 ;{ }^{* *} P<0.01$ (these values denote the effects of PN treatment $\times$ week interactions over the first 9 wk of age).

\section{DISCUSSION}

The results of the present study concur with results from several previous experiments in which larger amounts of milk or milk replacer were fed to calves. Calves fed HPN diets had increased overall growth, ADG, and G:F, which agrees with previous experiments in which calves were fed greater amounts of milk (Jasper and Weary, 2002; Khan et al., 2007) or milk replacer (Diaz et al., 2001; Blome et al., 2003; Bartlett et al., 2006; Cowles et al., 2006; Hill et al., 2008). These effects were maintained throughout the growing period.

Increased feeding rates of milk replacer increased growth but reduced consumption of starter throughout the milk feeding period, as observed in other studies where greater amounts of milk (Jasper and Weary, 2002; Borderas et al., 2009) or milk replacer (Jenny et al., 1982; Huber et al., 1984; Brown et al., 2005; Cowles et al., 2006; Hill et al., 2006b, 2008; Quigley et al., 2006) were fed. As a result, total DMI (milk replacer solids plus starter) by calves receiving HPN was greater than LPN during wk 2 and 3, but lower than LPN around and after weaning during wk 6 to 8 (Figure 3 ). Similar responses in total DMI before and after weaning were reported by Cowles et al. (2006) and Terré et al. (2007). In contrast, total DMI remained greater for calves initially fed about twice the volume of milk when milk intake was gradually decreased well before weaning (Khan et al., 2007).

Total water intake was increased by HPN treatments; in contrast, Quigley et al. (2006) and Bartlett et al. (2006) did not report any effect of feeding rates on water intake. However, water intake increased linearly 
Table 7. Least squares means for BW and body measurements during the liquid feeding ( 0 to 4 wk), weaning ( 5 to 7 wk), postweaning ( 8 to 12 wk), growing (15 to $20 \mathrm{wk}$ ), and residual (21 to $35 \mathrm{wk}$ ) periods for calves fed treatments varying in plane of nutrition (PN) and trace minerals (TM) source

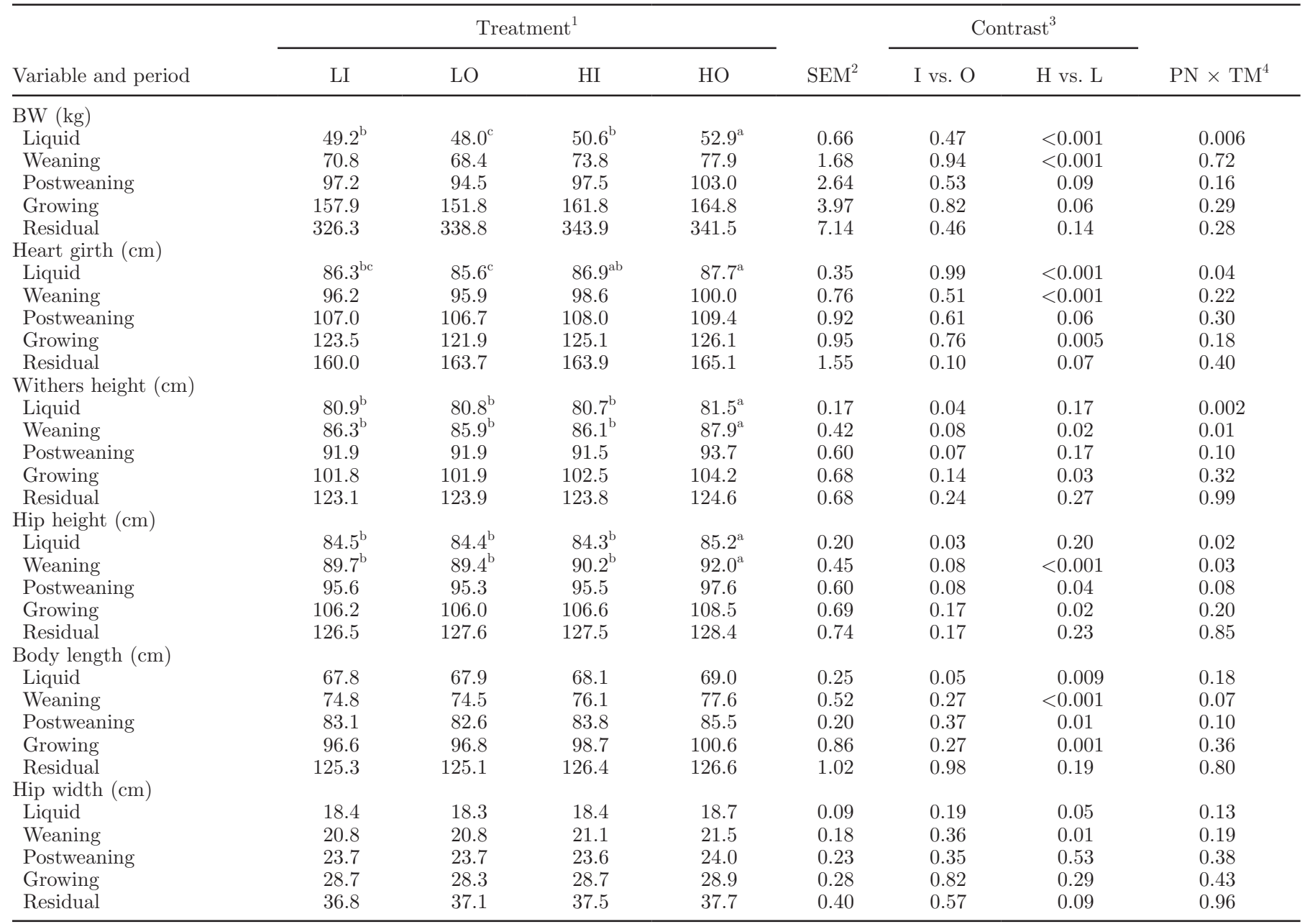

${ }^{\mathrm{a}-\mathrm{c}}$ Within a row, means without a common superscript are different $(P<0.05)$.

${ }^{1} \mathrm{LI}=$ low $(\mathrm{L}) \mathrm{PN}$, inorganic (I) TM; LO = low PN (LPN), organic (O) TM; HI = high (H) PN, inorganic TM (ITM); HO = high PN (HPN), organic TM (OTM).

${ }^{2}$ Largest SEM of all treatments.

${ }^{3}$ Contrast statements between ITM and OTM, and between HPN and LPN.

${ }^{4}$ Interaction between PN and TM treatment effects.

from wk 3 for LPN treatments, which is consistent with an increase in dry feed (starter) intake due to a constant nutrient supply from milk replacer against an increasing nutrient requirement for growth (Davis and Drackley 1998; NRC, 2001).

Although feces were more fluid for calves fed HPN, health status was not disturbed. Increased water intake by calves receiving HPN might have helped to maintain fluid balance, which did not happen in the Quigley et al. (2006) and Bartlett et al. (2006) studies. Although use of electrolytes was greater for calves fed treatment HI than for those fed HO, fecal scores did not differ between those treatments (Table 8 ).
Inclusion of OTM in milk replacer and starter fed to HPN calves increased calf BW during the liquidfeeding period and increased calf stature (as reflected in greater withers height and hip height) from liquidfeeding to postweaning periods, whereas OTM had no effect on these measures when supplemented in the LPN diet. These findings may suggest either that current recommendations (NRC, 2001) for TM are not adequate for calves growing at more rapid rates during early life or that OTM can overcome antagonisms among minerals or other dietary constituents that might influence absorption or utilization of TM. Interestingly, Bao et al. (2010) observed increased 

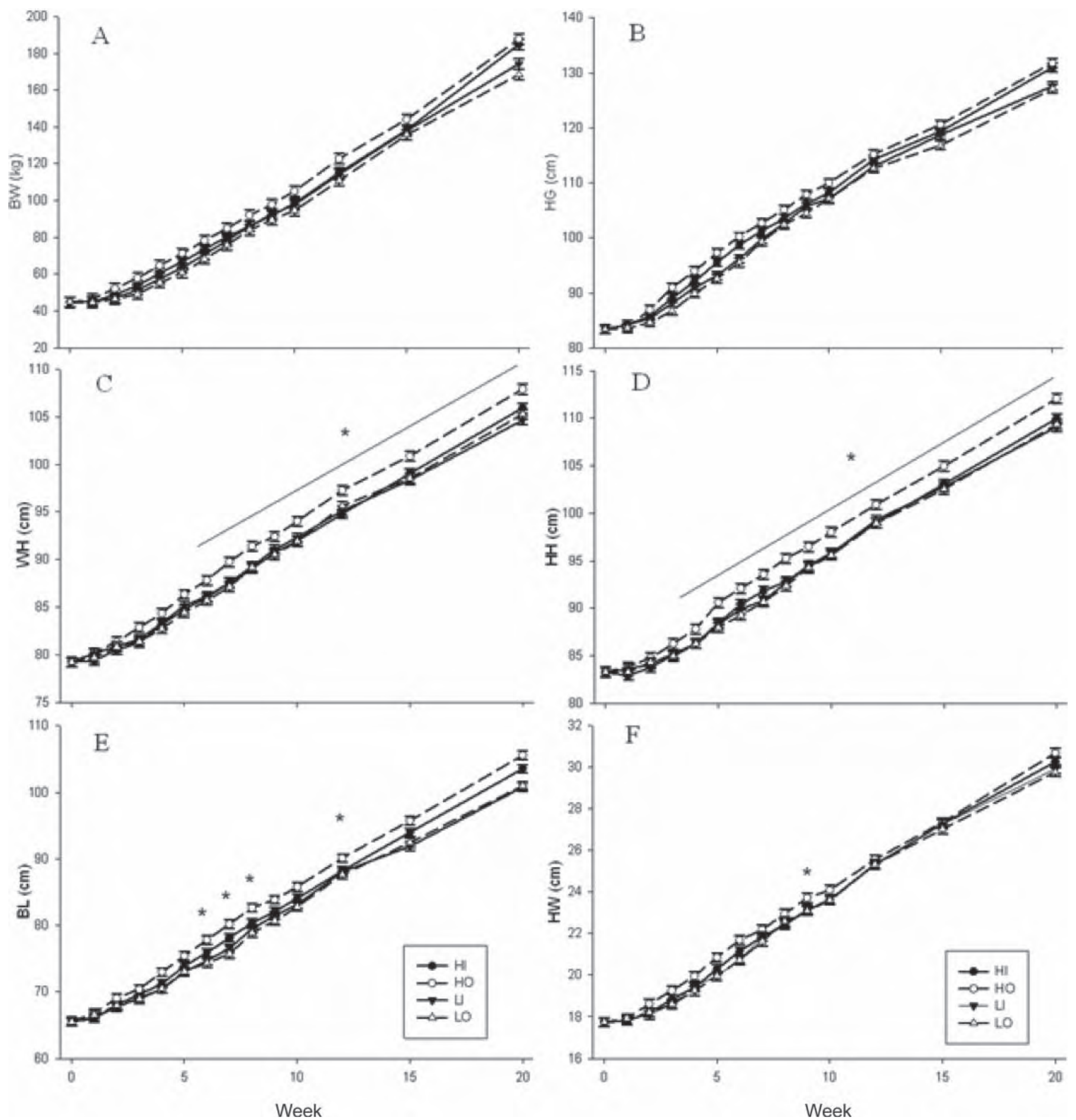

Figure 6. Mean weekly (A) BW, (B) heart girth (HG), (C) withers height (WH), (D) hip height (HH), (E) body length (BL), and (F) hip width (HW) from wk 0 to 20 for calves fed low (L) planes of nutrition (PN) and inorganic (I) trace minerals (TM) (LI; - $\mathbf{\nabla}$-), LPN and organic (O) TM (LO; - $\Delta-)$, high (H) PN and ITM (HI; - - $)$, and HPN and OTM (HO; - - $)$. * Denotes significant $(P<0.05)$ treatment combination HO $\times$ week interactions over the first 20 wk of age. Error bars denote pooled standard error.

feed intake, BW gain, and tibia bone length in broiler chickens when organic Zn was supplemented alone or combined with organic sources of $\mathrm{Cu}, \mathrm{Fe}$, and $\mathrm{Mn}$, supporting a role for OTM to positively affect bone formation and overall growth. Trace minerals (Zn, $\mathrm{Mn}, \mathrm{Cu}$, and $\mathrm{Fe}$ ) mediate a broad variety of catalytic, 


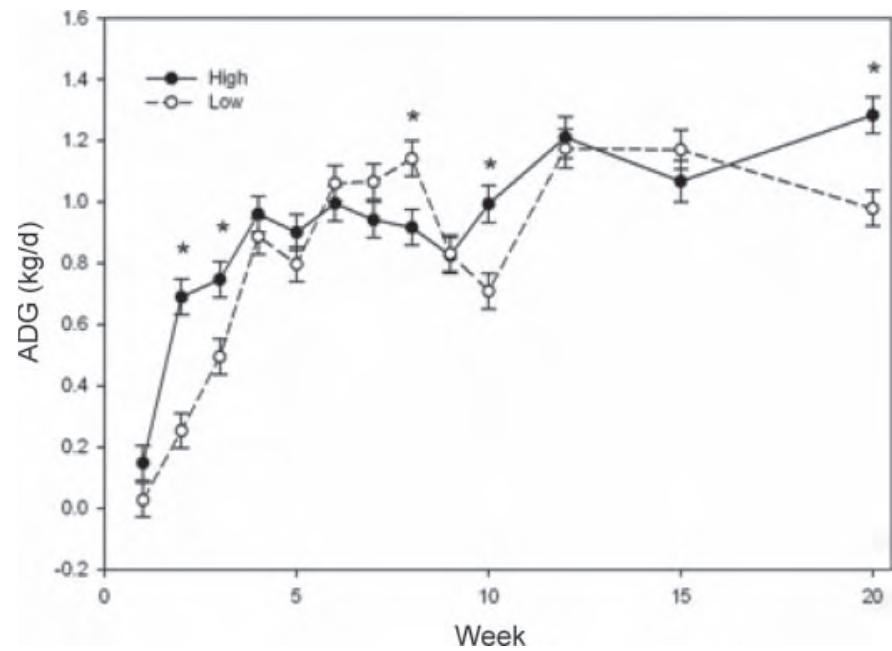

Figure 7. Average daily gain (with pooled standard error bars) from wk 1 to 20 for calves fed high (-๑-) or low (-O-) planes of nutrition. ${ }^{*}$ Denotes significant $(P<0.05)$ effects of treatment $\times$ week interactions over the first $20 \mathrm{wk}$ of age.

structural, and regulatory functions, such as RNA nucleotide transferases, RNA polymerase, alkaline phosphatase, and carboxypeptidase, among others (Cousins, 1996). Our results demonstrate that OTM supplementation further enhanced the retention of nutrients in a high nutritional program but not in a low program. Hence, increasing bioavailability of TM when larger amounts of macronutrients (i.e., HPN diets) are fed may optimize the rate and efficiency of calves to gain mass of body tissue.

Introduction of alfalfa hay to calves after $9 \mathrm{wk}$ might have added some variation of TM intake across time but not among treatments, as alfalfa hay contains dif-

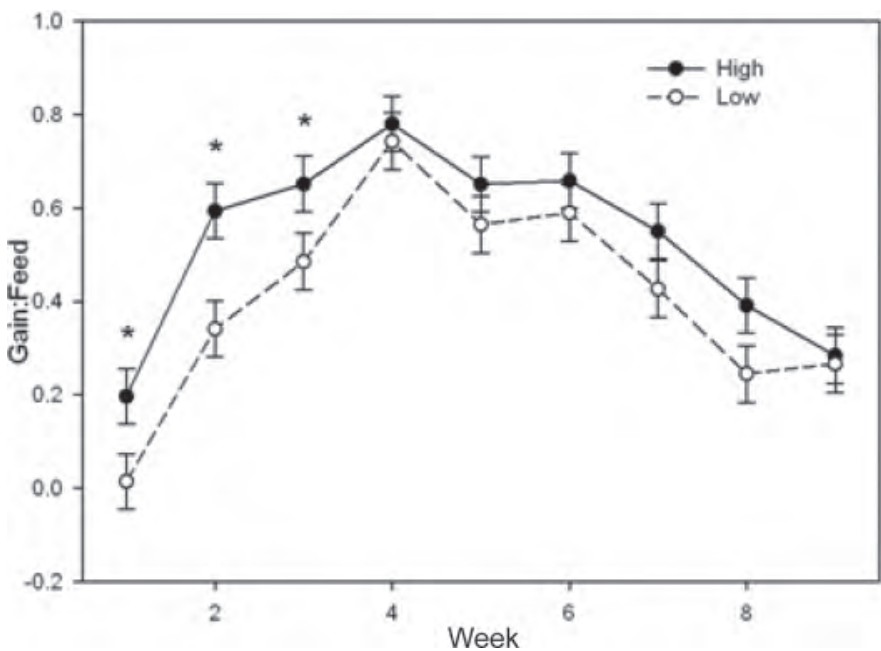

Figure 8. Mean gain:feed ratio (with pooled standard error bars) from wk 1 to 9 for calves fed high (-0-) or low (-O-) planes of nutrition. *Denotes significant $(P<0.05)$ effects of treatment $\times$ week interactions over the first $20 \mathrm{wk}$ of age.

ferent concentrations and availabilities of nutrients, depending on the vegetative stage at harvest as well as harvesting and storage procedures (Balde et al., 1993). However, increased consumption or bioavailability of TM might be expected to have a greater effect early in life, specifically on morbidity and mortality of calves that have been stressed by transportation, due to potential enhancement of immune capabilities. To some extent, this may be evident from Figure 9 where OTM calves had numerically greater survival percentages than ITM calves at wk 2. Similar results with TM have been reported by Boma and Bilkei (2009) in swine under other stressors such as adverse temperatures.

Table 8. Mortality characteristics, arrival mean IgG, daily fecal scores, days of scours, electrolytes, and antibiotics from wk 1 through 9 for calves fed treatments varying in plane of nutrition (PN) and trace minerals (TM) source

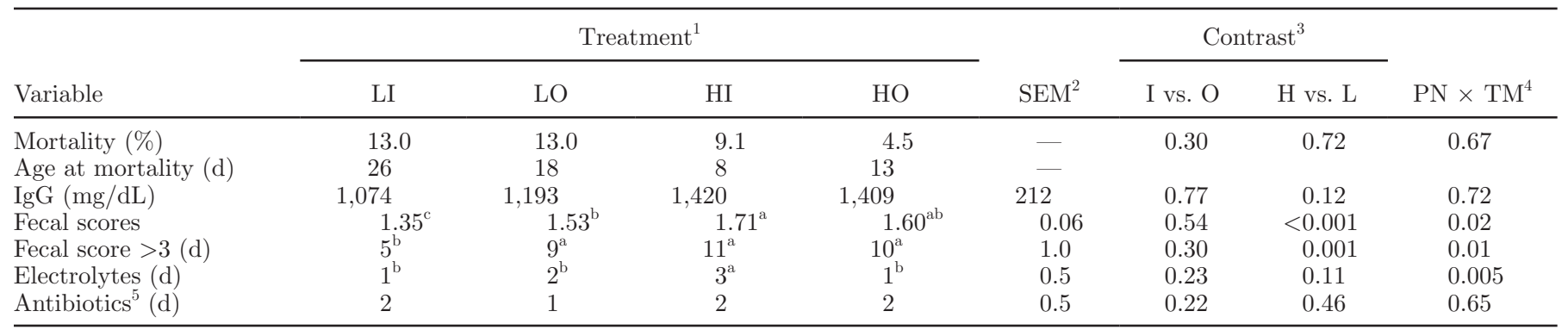

${ }^{a-c}$ Within a row, means without a common superscript are different $(P<0.05)$.

${ }^{1} \mathrm{LI}=$ low $(\mathrm{L}) \mathrm{PN}$, inorganic (I) TM; LO = low PN (LPN), organic (O) TM; HI = high (H) PN, inorganic TM (ITM); HO = high PN (HPN), organic TM (OTM).

${ }^{2}$ Largest SEM of all treatments.

${ }^{3}$ Contrast statements between ITM and OTM, and between HPN and LPN.

${ }^{4}$ Interaction between PN and TM treatment effects.

${ }^{5}$ Number of days treated for respiratory problems. 


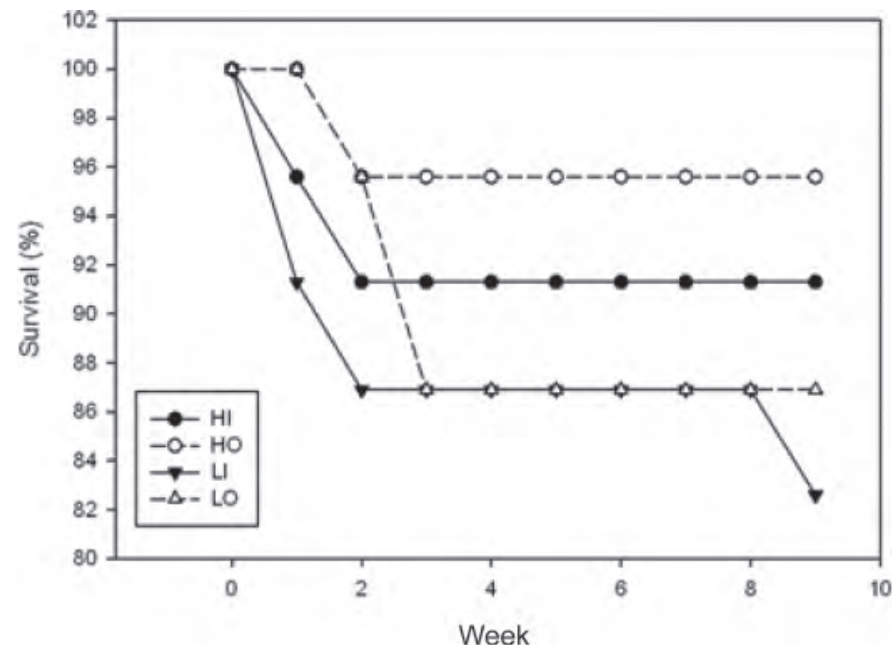

Figure 9. Survival curve from wk 1 to 9 for calves fed low (L) planes of nutrition (PN) and inorganic (I) trace minerals (TM) (LI; - $\mathbf{-}$ ), LPN and organic (O) TM (LO - $\Delta$-), high (H) PN and ITM (HI; -๑), and HPN and OTM (HO;-O-).

\section{CONCLUSIONS}

Our results described the responses of transported neonatal dairy calves to increased feeding rate of milk replacer and use of O over I supplemental TM sources. High PN treatments increased overall growth, ADG, and G:F through wk 20. Organic TM increased growth when supplemented to HPN but not when supplemented to the LPN program. Moreover, a presumed synergistic interaction occurred between HPN and OTM to enhance growth when fed in combination. Organic TM increased animal stature, as reflected in greater withers and hip height. Although feces were more fluid, calves fed HPN did not have impaired health status, perhaps due in part to an increase in free water; consequently, increased total water intake through 5 wk of age may have contributed to homeostatic fluid balance. Small residual effects of HPN intake were present at wk 35 for heart girth and hip width. In the same way, residual effects of OTM tended to result in greater heart girth at wk 35 .

\section{REFERENCES}

AOAC. 1990. Official Methods of Analysis. 15th ed. Assoc. Offic. Anal. Chem., Arlington, VA.

AOAC International. 2003. Official Methods of Analysis. 17th ed. AOAC International, Gaithersburg, MD.

Balde, A. T., J. H. Vandersall, R. A. Erdman, J. B. Reeves III, and B. P. Glenn. 1993. Effect of stage of maturity of alfalfa and orchardgrass on in situ dry matter and crude protein degradability and amino acid composition. Anim. Feed Sci. Technol. 44:29-43.

Ballantine, H. T., M. T. Socha, D. J. Tomlinson, A. B. Johnson, A. S. Fielding, and J. K. Shearer. 2002. Effects of feeding complexed zinc, manganese, copper, and cobalt to late gestation and lactating dairy cows on claw integrity, reproduction, and lactation performance. Prof. Anim. Sci. 18:211-218.

Bao, Y. M., M. Choct, P. A. Iji, and K. Bruerton. 2010. Trace minerals interactions in broiler chicken diets. Br. Poult. Sci. 51:109-117.

Bartlett, K. S., F. K. McKeith, M. J. VandeHaar, G. E. Dahl, and J. K. Drackley. 2006. Growth and body composition of dairy calves fed milk replacers containing different amounts of protein at two feeding rates. J. Anim. Sci. 84:1454-1467.

Blome, R. M., J. K. Drackley, F. K. McKeith, M. F. Hutjens, and G. C. McCoy. 2003. Growth, nutrient utilization, and body composition of dairy calves fed milk replacers containing different amounts of protein. J. Anim. Sci. 81:1641-1655.

Boma, M. H., and G. Bilkei. 2009. The effects of low levels of dietary trace minerals on the plasma levels, faecal excretion, health and performance of pigs in a hot African climate. Onderstepoort J. Vet. Res. 76:291-297.

Borderas, T. F., A. M. B. de Passillé, and J. Rushen. 2009. Feeding behavior of calves fed small and large amounts of milk. J. Dairy Sci. 92:2843-2852.

Brown, E. G., M. J. VandeHaar, K. M. Daniels, J. S. Liesman, L. T. Chaplin, and D. H. Keisler. 2005. Effect of increasing energy and protein intake on body growth and carcass composition of heifers calves. J. Dairy Sci. 88:585-594.

Chigerwe, M., J. W. Tyler, D. W. Nagy, and J. R. Middleton. 2008. Frequency of detectable serum IgG concentrations in precolostral calves. Am. J. Vet. Res. 69:791-795.

Cousins, R. J. 1996. Present Knowledge in Nutrition. 7th ed. E. E. Ziegler and J. J. Filer Jr. ILSI Press, Washington, DC.

Cowles, K. E., R. A. White, N. L. Whitehouse, and P. S. Erickson. 2006. Growth characteristics of calves fed an intensified milk replacer regimen with additional lactoferrin. J. Dairy Sci. 89:48354845.

Dairy One. 2007. Forage lab analytical procedures-February 2007. Accessed June 10, 2009. http://www.dairyone.com/Forage/Procedures/default.htm.

Davis, C. L., and J. K. Drackley. 1998. The Development, Nutrition and Management of the Young Calf. 1st ed. Iowa State University Press, Ames.

Diaz, M. C., M. E. Van Amburgh, J. M. Smith, J. M. Kelsey, and E. L. Hutten. 2001. Composition of growth of Holstein calves fed milk replacer from birth to 105-kilogram body weight. J. Dairy Sci. 84:830-842.

Griffiths, L. M., S. H. Loeffler, M. T. Socha, D. J. Tomlinson, and A. B. Johnson. 2007. Effects of supplementing complexed zinc, manganese, copper, and cobalt on lactation and reproductive performance of intensively grazed lactating dairy cattle on the south island of New Zealand. Anim. Feed Sci. Technol. 137:69-83.

Hill, S. R., K. F. Knowlton, K. M. Daniels, R. E. James, R. E. Pearson, and A. V. Capuco. 2008. Effects of milk replacer composition on growth, body composition, and nutrient excretion in preweaned Holstein heifers. J. Dairy Sci. 91:3145-3155.

Hill, T. M., J. M. Aldrich, R. L. Schlotterbeck, and H. G. Bateman. 2006a. Effects of feeding calves different rates and protein concentrations of twenty percent fat milk replacers on growth during the neonatal period. Prof. Anim. Sci. 22:252-260.

Hill, T. M., J. M. Aldrich, R. L. Schlotterbeck, and H. G. Bateman. 2006b. Effects of feeding rate and concentration of protein and fat of milk replacers fed to neonatal calves. Prof. Anim. Sci. 22:374381

Huber, J. T., A. G. Silva, O. F. Campos, and C. M. Mathieu. 1984. Influence of feeding different amounts of milk on performance, health, and absorption capability of baby calves. J. Dairy Sci. 67:2957-2963.

Jasper, J., and D. M. Weary. 2002. Effects of ad libitum milk intake on dairy calves. J. Dairy Sci. 85:3054-3058.

Jenny, B. F., H. J. Van Dijk, and L. W. Grimes. 1982. Performance of calves fed milk replacer once daily at various fluid intakes and dry matter concentrations. J. Dairy Sci. 65:2345-2350.

Khan, M. A., H. J. Lee, W. S. Lee, H. S. Kim, S. B. Kim, K. S. Ki, J. K. Ha, H. G. Lee, and Y. J. Choi. 2007. Pre- and postweaning 
performance of Holstein female calves fed milk through step-down and conventional methods. J. Dairy Sci. 90:876-885.

Littell, R. C., P. R. Henry, and C. B. Ammerman. 1998. Statistical analysis of repeated measures data using SAS procedures. J. Anim. Sci. 76:1216-1231.

Nocek, J. E., M. T. Socha, and D. J. Tomlinson. 2006. The effects of trace minerals fortification level and source on performance of dairy cattle. J. Dairy Sci. 89:2679-2693.

NRC. 2001. Nutrient Requirements of Dairy Cattle. 7th rev. ed. Natl. Acad. Press, Washington, DC.

Quigley, J. D., T. A. Wolfe, and T. H. Elsasser. 2006. Effects of additional milk replacer feeding on calf health, growth, and selected blood metabolites in calves. J. Dairy Sci. 89:207-216.

Siciliano-Jones, J. L., M. T. Socha, D. J. Tomlinson, and J. M. DeFrain. 2008. Effect of trace mineral source on lactation perfor- mance, claw integrity, and fertility of dairy cattle. J. Dairy Sci 91:1985-1995.

Stanger, K. J., N. Ketheesan, A. J. Parker, C. J. Coleman, S. M. Lazzaroni, and L. A. Fitzpatrick. 2005. The effect of transportation on the immune status of Bos indicus steers. J. Anim. Sci. 83:2632-2636.

Terré, M., M. Devant, and A. Bach. 2007. Effect of level of milk replacer fed to Holstein calves on performance during the preweaning period and starter digestibility at weaning. Livest. Sci. 110:82-88.

Tikofsky, J. N., M. E. Van Amburgh, and D. A. Ross. 2001. Effect of varying carbohydrate and fat content of milk replacer on body composition of Holstein bull calves. J. Anim. Sci. 79:2260-2267. 